\title{
Becoming the role model: Youth recreational leaders, occupational choice and a will to include.
}

\author{
Andreas Fejes and Magnus Dahlstedt \\ Journal Article
}

\section{Tweet}

N.B.: When citing this work, cite the original article.

This is a postprint version of an article published in:

Andreas Fejes and Magnus Dahlstedt, Becoming the role model: Youth recreational leaders, occupational choice and a will to include., Discourse. Studies in the Cultural Politics of Education, 2017.

Discourse. Studies in the Cultural Politics of Education is available online at informaworldTM:

http://dx.doi.org/10.1080/01596306.2017.1308917

Copyright: Taylor \& Francis (Routledge)

http://www.routledge.com/

Postprint available at: Linköping University Electronic Press

http://urn.kb.se/resolve?urn=urn:nbn:se:liu:diva-136470

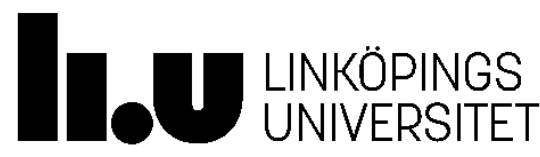




\title{
Becoming the role model: youth recreation leaders, occupational choice and a will to include
}

Andreas Fejes \& Magnus Dahlstedt

Linköping University

andreas.fejes@liu.se, magnus.dahlstedt@liu.se

\section{Full reference:}

Fejes, A. \& Dahlstedt, M. (2017) Becoming the role model: youth recreation leaders, occupational choice and a will to include. Discourse: Studies in the Cultural Politics of Education. doi.dx.doi.org/10.1080/01596306.2017.1308917

\begin{abstract}
The aim of this article is to analyse how a discourse on the role model operates in youth recreational work. Drawing on Michel Foucault's concepts of subjectivity, discourse and power/knowledge, the article analyses interviews with youth recreation leader students enrolled at a folk high school, and their talk about occupational choice. The analysis illustrates how a discourse on the role model emerge and operate through the ways students' descriptions of 'being', and 'doing' intersect with their becoming as role models. The analysis raises several important questions. Should youth recreational work only target those young people who are already marginalised? Are there other subject positions than the role model, available to take up in youth recreation work? Are experiences of marginalisation necessary in order for a desirable youth recreation leader to emerge?
\end{abstract}

\section{Introduction}

During the last few years, there have been social tensions and escalating conflicts among young people in the suburbs of cities across Sweden. These tensions have introduced an intensive debate about the exclusion of young people. One of the key issues addressed in the debate has been the importance of meaningful leisure time activities in general, and specifically the importance of youth recreation centres (Ungdomsstyrelsen, 2008). This issue has been targeted by suburban youth, who have taken action, occupying a number of houses and focusing explicitly on local meeting points for young people which were under threat of closure, such as youth recreation centres (see e.g. Dahlstedt, 2009). Leisure time activities have emerged as a possible reason for, as well as a possible solution to the growing social problem of exclusion of young people. For a long time, youth recreation centres have been used as a means of reaching out to and socialising socially-excluded youth (Blomdal \& Claesson, 1989). The aim of this intervention is to prevent criminality and deviant behaviour, and promote positive personal development in the young people taking part (Bjurström, 2011).

One of the ways of addressing the exclusion of young people has been to engage workers who themselves have experience of exclusion, and who have managed to break free from e.g. criminal backgrounds, to work with the young people in the suburbs (Ekholm, 2016; Öhlund, 2016). The hope is that they will then act as role models for the young people, thus compensating for what is regarded as a lack of good role models in the suburbs (Dahlstedt \& Lozic, 2016). This type of discourse raises questions about who an individual needs to "be" in order to become a youth recreation leader. By focusing on students who are training to be youth recreation leaders and how they talk about their occupational choice, we wish to identify how a discourse on role models operate, and with what effect. Thus, we aim to make a critical contribution to current debates on role models, the exclusion of young people and youth recreation work.

\section{Occupational choice}


An extensive body of literature addresses issues such as occupational choice and career aspirations. This has shown that occupational choices are based on intrinsic and/or extrinsic factors (Fejes \& Nicoll, 2010). In the literature, these choices have been explained in different ways: in terms of rational decision-making (for an overview, see Billett, Newton and Ockerby, 2010), in terms of social structures and processes (Simpson, 2005; Gottfredson \& Lapan, 1997) and in terms of personal values and life histories (Billett, Newton \& Ockerby, 2010). In literature on learning and occupational aspirations, there has been a call for the development of a more situational understanding of occupational choices, focusing on how these choices are actually made, and what motivates individuals to choose certain careers (Billett et.al., 2010). Occupational choices are part of our learning careers and life histories; learning is connected to 'identity and situation and cannot be extracted from them' (Bloomer \& Hodkinson, 2000, p. 595). Thus, it is argued that there is a need for a greater focus on individuals' learning careers, and how these are connected to wider social structures, to understand the how and why of occupational choices (see e.g. Hodkinson \& Sparkes, 1997; Bloomer \& Hodkinson, 2000; Billett et al., 2010).

Socio-culturally informed research suggests that individuals 'self-identify' with a vocation through education in a whole range of vocational spheres (Ecclestone \& Pryor, 2003; Volman \& ten Dam, 2007). As Colley, James, Tedder, and Diment. (2003, p. 488) suggest in a review of the literature on vocational habitus, self-identification is a central part of student learning, and a process of orientation towards an identity as 'the right person for the job'. They conclude that there is a complex interplay between processes of social acculturation and individual agency in this process of orientation. For them, student orientations emerge as idealised and realised identities, related to student disposition, but also to predisposition as a product of social and family background, gender, individual preference and life experiences. In a study of childcare, engineering and health-care students, Colley, James and Diment (2007) illustrate how, to a greater or lesser extent, all students 'become' vocational workers when they talk about themselves, though in very different ways. Those who failed to orient themselves in this way were found to 'unbecome'. Self-identification is thus insecure. It may cut across other priorities for the individual in complex ways which require negotiations of the self with the self, and may result in refusals.

\section{Youth recreation education and work}

A youth recreation leader is a specific pedagogic occupation in Sweden, and education for youth recreation leaders is organised at folk high schools. Folk high schools goes back 150 years and are part of a specific Nordic and Swedish tradition of popular education. Here, nonformal education is organised, without any formal state sanctioned curriculum, but rather a central characteristic of folk high schools (and popular education more widely) is that they are "free and voluntarily". Today there are 154 folk high schools in Sweden owned by either the regional counties (approximately 1/3) or the social movements (the rest). Owners thus include public organisations, unions, political parties, religious organisations, etc. (see e.g. Laginder, Norvall \& Crowther, 2013).

After graduation from the youth recreation leader program, the context of work is primarily youth recreation centres, which are places where young people can take part in leisure time activities free of charge. The target groups of these centres are broad, i.e. all youths who are interested in attending the activities organised. However, youth recreation centres have had a specifically important role for those young people who are marginalised, or in risk of marginalisation. Thus, these centres have become important meeting places in socially vulnerable areas, not least for young people with working class and migrant backgrounds in 
suburban areas throughout Sweden (Peterson, Svensson, \& Addo, 2003). The centres are construed as places which provide the conditions for play, recreation and relaxation, i.e. places for learning which are different from the more formalised learning in schools (Kihlström \& Roos, 2000; Roos, 2000; Bjurström, 2011). However, this type of informal learning has been seen as important in terms of what happens at school (Trondman, 2000; Sivan, 2003), thus addressing the issue of the professionalism of youth recreation leaders (Forkby, Johansson \& Liljeholm Hansson, 2008).

Good relations between young people and adults have been cited as an important part of the learning which takes place in the centres, where the recreation leader becomes a role model, an adult who can guide and acknowledge the young people. Blomdal and Claesson (1989) argue that the centres are successful in reaching out to young people, and especially those who are able to express themselves. However, they also argue that there is a risk that youth recreation leaders may not have high enough ambitions in terms of challenging and stimulating the young people to overcome their exclusion. Kihlström and Roos (2000) point to similar issues. They argue that recreation leaders need to develop interactive competence, which they communicate to and develop in the young people themselves. This competence involves the ability to communicate and acknowledge young people's experiences as a starting point for listening to and acknowledging their development in society.

In sum, there has been a shift during the last few years, where the target groups of youth recreation centres have shifted (not formally, but in practice), from helping young people in risk of marginalisation, to helping those that are already marginalised. A key discourse emerging here is the need for role models who themselves have experience of marginalisation. Such role models will be able to help marginalised youngsters to become included in society. With such developments, it thus becomes important to further scrutinize in what ways such discourse on the role model operates among students who themselves are training become youth recreational workers, and with what effects.

\section{Theoretical and methodological considerations}

In order to analyse a discourse on the role model operates in students talk we draw on the work of Foucault (1972, 2007, 2008) and education scholars who have engaged with his work (Fejes \& Dahlstedt, 2014; Fejes \& Nicoll, 2015). We specifically draw on the concepts of subjectivity and discourse. Self-identification is understood here as descriptions of subjectivity, where there is no a priori self as an object or thing. The 'self' is decentred and analysed as it is shaped in specific ways through language. This decentring involves the potential for describing a multiplicity of subjectivities, and multiple and partial uptakes and elisions, but these may take specific forms through the regularities of description. In this way, the effect of the power-knowledge constellations of the discourses is made available to draw on. At any time, we are positioned in what we can say by our location within powerknowledge regimes, and we describe ourselves in relation to what is discursively available to draw on in that location. Subjectivities emerge through and within the regularities of selfdescription. Thus, the ways in which youth recreation leaders construe themselves as role models are connected to wider discourses which are available for them to draw on. These discourses emerge from, and can be identified through regularities of statements which become available to us as researchers through student interviews.

In order to identify regularities of statements, we draw here on interviews conducted with nine students enrolled at the youth recreation leader programme at one folk high school in Sweden. The regional county owns the school and thus the school and its curriculum is 
ideologically neutral in terms of political parties, and religion. The two year program includes studies in e.g. sociology, psychology, health, drama, and leadership. The nine interviews are part of a larger research project on citizenship education within and beyond adult and popular education, where the aim is to understand how adult students "do" citizenship in their everyday life. As male students dominate the youth recreation programme, an equal sample based on gender was not possible. Interviews were conducted with seven male and two female students. The interviews covered areas such as why the students chose to engage in youth recreation studies (i.e. occupational choice), their background, their ideas about the future, and their ideas about what they do in their everyday life, which is effectively "doing" citizenship" (for the wider project, see e.g. Nicoll et al., 2013; Olson et al., 2015; Sandberg et al., 2016; Fejes et al., 2016).

Interviews were transcribed in verbatim and our analysis focused on regularities of statements, which emerged from the interview transcriptions. Discourse makes certain statements more or less possible, at the same time, as statements constitute discourse. Thus, the way students talk about themselves and their occupational choice participate in the construction of discourse on youth recreational work, at the same time as such discourse make certain ways to talk possible. Our analytical focus is thus directed at the discursive work of what students talk about rather than students' cognitive functions or understandings.

\section{'Being', 'doing' and 'becoming' a youth recreation leader}

By reading the transcribed interviews with a focus on how students describe themselves and their occupational choice, we identified regularity of statements in terms of how the role model emerge as central to youth recreational work. More specifically, the role model emerge through a logic of connecting descriptions of past experiences of marginalisation, with descriptions of concrete actions and activities aimed at change, to descriptions of a wish to become a role model in the future. Thus, the ontological 'beings' (who am I/who have I been?) merge with epistemological 'doings' (what have I done which is important in terms of choosing this occupation?) as a basis for how the youth recreation leader 'becomes' a role model (what do I wish to contribute by being a youth recreation leader?). In the following, we draw on this logic in order to pursue our argument. The analysis is divided into three sections: the ontological 'beings', the epistemological 'doings' and 'becoming' the role model. We use quotations from interviews with students in order to illustrate our argument. All names of students are fictive.

\section{The ontological beings}

In all interviews, the ontological 'beings' of those interviewed emerge through description, which in turn serve to explain and legitimise the occupational choices of students. These ontological 'beings' relate to certain characteristics in the past as well as the present. However, a common denominator is how the students shape their 'being' as a phenomenon outside of normality. They all, in some way, describe themselves as someone who currently does not, or who previously did not, quite fit into what can be described as a normal 'being'.

Edwin describes how he has lived outside of normality as a criminal; during his younger years he stole, burgled and was nasty to other people. At the same time, he mobilises an idea of the possibilities for change, i.e. how a person can become someone different to the person they are at the moment.

I've done a lot of bad things in my life ... burglaries, stealing, going into a shop and stealing a jacket without paying. You treat other people like shit, and that's who I was, but people can change. 
He goes on to describe how much like his father he is. His father was also once a criminal who spent time in prison, but has now changed his life path and become a youth recreation leader, engaging in a number of recreational activities. He noted during the interview:

I'm very much like my father. He has also been in prison, and despite this, he set up several youth recreation activities, night walkers and things like that.

Here we see how Edwin, who has a criminal background, positions himself, through description, as having the same characteristics as his father. As described, both have lived outside of normality, with criminal backgrounds, and both wish to work in youth recreation.

In a similar way, Albin relates the experiences of his father to the way he himself has lived. Like Edwin, Albin describes himself as growing up outside of normality, with a criminal background. On the other hand, he describes how his father, who is a youth recreation leader, inspired him to change and become someone else, as did other youth recreation leaders he met during his school years.

I acted up, especially during my secondary school years. Criminal things and such like. My anger at school was directed at society instead, so to speak. So things changed and had the opposite effect in the end during the middle of my upper secondary school years, when I wanted to give back instead ... I had very good contact with youth recreation leaders during secondary school. I had a lot of support in developing my personality. They became my role models ... so that's the reason why I chose to become a youth recreation leader. I look up to my father quite a lot, and he's also a youth recreation leader.

The logic constructed here is that Albin's 'being' changed as a result of role models such as his father and youth recreation leaders he met during secondary school. The logic involves the fact that he was once a criminal, and then something happened; he changed and became something else. This change is the basis for his wanting to become a youth recreation leader.

Alma describes herself as being outside of normality differently from Edwin and Albin. In the interview, she construes herself as not very knowledgeable, and she says she never felt comfortable at school; she did not quite fit in. This changed when she became a member of the church and active in its various activities. She describes how she felt more at home at church, a place where she was not judged as she was at school. Rather, she was acknowledged for who she was, her 'being'. As she states in the interview:

\footnotetext{
When I became a member of the church, I learnt a lot about this. They were very happy when I went there. I experienced a totally different community from the one at school ... I've always been a person who doesn't know very much. This [her youth recreation leader studies] is really what I know. This is what I think is interesting: leadership and group development, and how you can view people without judging, to see that there are different perspectives on things. All of that, this is how I generally think in everyday life, so I believe that everything here [at the youth recreation leader programme] fitted in so well. That's why I think it's so much fun to be here, as everything here aims towards these things, caring for others.
}

Alma positions herself as someone outside of normality in terms of school, but at the same time as someone who, based on this experience, can care for others. Caring for others is construed as the primary aim of being a youth recreation leader.

Drawing on descriptions of their 'being', as seen so far, acts as a resource for talking about the reason to embark on youth recreation leader studies. The same logic emerges in the 
interview with Robin where she positions herself outside of normality, indicating that she does not fit in.

\begin{abstract}
I wanted to celebrate when I got an explanation for why I'd acted differently to others and why I didn't feel like fitting in and such things. At the same time, it was sad, as this is a chronic disease which I'll always have to handle for the rest of my life ... first I become manic for a week, and then I'm really active, and then I do a belly flop, and I was ill for half a year, my first period. I couldn't do anything; I was totally paralysed in most ways.
\end{abstract}

Her illness is construed here as part of her ontological being. She construes being who she is, and the experience of 'not fitting in' as a resource in relation to her future work as a youth recreation leader, where she will care for others.

So far, we have illustrated how there are regularities of descriptions in terms of how the students construe their ontological beings as outside of normality. These abnormal (cf. Foucault, 1991) beings are positioned as a basis and a resource for the desire to become someone else, i.e. becoming normal and belonging to the inside.

\title{
The epistemological 'doings'
}

This section focuses on the 'doings' emerging as important resources in the ways students describe their own trajectory of becoming normal, in developing a sense of meaning and belonging. Several of the interviews contain descriptions of how the students 'do' leisure time activities, whether these be sports, scouting or music. These 'doings' act as resources in legitimising and explaining students' occupational choice. Albin, who described himself in the previous section as someone with a criminal background, tells us that his interest in music was important in terms of his trajectory of leaving his criminal background behind.

My greatest interest is music, and I also have an interest in games, but not as much as before. But the greatest interest that made me engage so much is music. I was unhappy in secondary school and in upper secondary school, so I got involved in activities for young people outside school instead, such as music and things.

Here, 'doing' musical activities is construed as acting as a resource in Albin's movement into becoming normal, as well as for his early engagement in youth recreation work. These activities are also construed as something he can draw on in his current studies and future work. Similar ways of using musical activities as a resource emerge in the interview with Melvin. He positions 'doing' music, as well as sports in terms of being an ice hockey referee, as important activities he draws on in terms of his current studies and his future work.

Creating music and being involved in ice hockey, these are a bit different, sports and music. That's what I do during my leisure time. I'm either a referee in ice hockey, or I make music ... I feel that I've developed leadership abilities from being a referee, by being a leader on ice, so that's the key, so to speak, that I want to become a leader.

The logic emerging from the interview is that being an ice hockey referee has provided Melvin with experience of leadership, which in turn has been an important resource on which to base the choice of becoming a youth recreation leader.

Simon, another student, describes how his interest in scouting, and his experience as a scout leader, have acted as an important basis for his choice to become a youth recreation leader.

I've been a scout leader and had the benefit of actually working with young people during their leisure time, and I've found it to be fun and rewarding, and that it would suit me at the same 
time, as I'll maybe have the chance to use my experience of outdoor life at work, and you might say this is the reason why I'm here.

Here, scouting does not only emerge as providing something fun and rewarding. Specific aspects of scouting are also constructed as a resource in relation to future work. A similar logic emerges in Nabins description. Here activities as a dance teacher and practising parkour with young people are construed as important resources in making a career choice.

I started to do parkour. I started to teach dancing, and all of this, then I felt like working with people more than anything else ... I've been working as a dance teacher for a short while now, and I thought that I could engage in an educational programme that had something to do with kids and youth. I'd never thought of that before.

A quite different form of 'doing' emerge as important basis for career choice in Alma's description: engaging in activities for young refugee boys:

A nice thing that I'll never forget is when we organised, through the church, a skiing camp in cooperation with a home for young refugee boys. So we worked with them, some of them had only been in Sweden for a few months. The one who had been in Sweden the longest had been here for one year. So that was the longest, so he knew Swedish very well, but the others were hard to understand. They came from everywhere, from all over Sweden or from all over the world. It was really interesting to go there, because it was a culture shock; they'd never been skiing and they hadn't even seen snow before.

Here, activities involving organising a ski camp for young refugee boys, a group of people who are positioned in public discourse on the outskirts of normality in Swedish society (Wernesjö, 2014), act as a resource in Alma’s description of her choice of career.

So far, we have illustrated how there are regularities in the descriptions in terms 'doing' leisure time activities, and how 'doings' act as resources in a process of normalisation, as well as for legitimating choice of career.

\section{'Becoming' the role model}

This section focuses on how, in the interviews, students' 'beings' and 'doings' merge with the process of 'becoming' youth recreation leaders. Together, 'beings' and 'doings' act as resources, not only in terms of making possible career choices, but also in making possible a discourse on the role model.

In the interview with Edwin, a youth recreation leader is construed as someone who should help others, creating places where people of different backgrounds can meet, and someone who should facilitate mutual understanding between these different people.

Hopefully, [in ten years] I will have launched more than one youth recreation centre, and my goal is to help people, maybe not help them in that way, but to create a place where they can be and hang out and get to know each other. And to introduce the idea that people with different backgrounds can hang out ... It's very hard for immigrants ... and I wish to show how there are no differences between us. Because my best friend from when I was young, he's an immigrant. And these students like me. But they speak as if immigrants are bad, and then I want to show them, then I can bring my friend and show that he's exactly like me. That's what I want to do.

Here, Edwin shapes the ideal of the youth recreation leader as someone who should and can provide young people with perspectives, and help them learn to understand and respect people with different backgrounds. He describes how, in his work, he uses himself and his friend as role models, as people the young people should look up to, whose good example they should 
learn from and follow. This particular notion of the youth recreation leader as a role model connects back to how Edwin himself, as illustrated previously, describes his father as his role model, someone with similar experiences to himself, who managed to leave behind a criminal background and do something productive for himself as well as for others.

Nabin, who construes himself as an immigrant, and as such positioned on the outskirts of Swedish normality, contributes in a different way to shaping youth recreation leaders as role models. He describes how it took him a long time to discover what he wanted to do in life, and in the following quotation he describes how he draws on this particular experience of struggle in his own teaching.

But think of it like a hard assignment at school where you think, “No, I won't succeed.” You can compare this to a high wall that you can't climb, but you'll find your own way to climb it at the end of the day. This is how you do it. You try and you never give up, and it's only about holding on and believing in yourself. That's what I talk about a lot with my students.

Here, Nabin connects his 'being', his experience of struggling to find his own way in life, with his 'doings' as a dance teacher. He thus positions himself as a role model, as someone who has something important to teach others, particularly young people, based on his own forms of being and doing.

In different ways, Melvin and Alfred construe themselves as role models who will help give young people a second chance. As Melvin tells us:

As a youth recreation leader, you feel like you're there for the young people, and they need this. No matter how far down they are in the shit, you can always pull them up, so I feel, so those who have a tough time, you still give them a chance, and that's important, to give them a chance.

Here Melvin positions youth recreation leaders as people who help young people, giving them a second, and maybe a third and fourth chance. Alfred speaks in similar ways when he talks about giving something back to the place he comes from. He describes how he had support from youth recreation leaders as role models when he was young, and now he wants 'to be like them'.

I wanted to become a youth recreation leader because I had role models who worked, who were youth recreation leaders when I was young, and I looked up to them and felt that I wanted to be like them. So that's why I've taken this path. It would be good to work in my home city and in the youth centre I went to myself when I was young. It would be really fun to work there ... Just to be there for the young people, maybe just to speak or play cards or billiards, or just to be there for them as an adult. That's how I feel.

In describing his decision to become a youth recreation leader, Alfred highlights the importance of being a role model. Role models were the reason he 'took this path', and now he wishes to become one himself. In Alfred's description, a role model is an adult who can be there for the young people.

So far, a role model has been construed as someone who is working with and engaging with young people. However, there are also descriptions in which role models have a broader function. In the interview with Robin, a youth recreation leader emerges as someone who can relate to anyone as a role model, whether it be a child, young person, adult or older person. Recreation work is construed here as engaging anyone in active leisure time. As Robin notes: 
I want to work with young people, maybe also older people and adults, and children, and on projects. I previously studied project management, and I want to strengthen that profile by studying to become a youth recreation leader. And I believe that everyone has a right to active leisure time, and it's important for everyone's lives, and I hope a lot of people see it that way.

Robin shapes herself here as a role model, as someone who helps others to engage in active leisure time activities. Her position as a role model is not confined to the youth recreation centre. She also reaches out to people, places and activities outside this domain, guided by the belief that 'everyone has a right to active leisure time'.

In this section, we have illustrated regularities in the descriptions in terms of how students' 'beings' and 'doings' merge with their 'becoming' youth recreation leaders, and how these are construed in a certain way, i.e. as role models.

\section{Discussion}

This article has illustrated how a discourse on the role model operates strongly in youth recreation leader students talk about their occupational choice. Despite different 'beings' and 'doings' emerging in student interviews, a stable logic emerges where students' 'beings' and 'doings' intersect and make possible their 'becoming' as role models. Where students' own 'beings' are shaped as outside the mainstream, such as those with experience of being a criminal, someone with psychological problems or an immigrant, this is positioned as a resource in order to engage in different forms of 'doings', such as dance, parkour, music, scouting and acting as a hockey referee. These 'doings' is a path towards normality. Together, 'beings' and 'doings' thus make possible students choice of career, i.e. a choice to become a role model.

The role model is thus a subject position to which all students aspire, or in other words, the role model is an effect of the discourses operating in students talk about their occupational choice. A role model is constructed as someone who primarily engages with troubled youths, someone who provides guidance, meaningful leisure time activity and a second, third or maybe fourth chance. Several students draw on experiences of role models in their own lives in terms of how they themselves have become role models, such as their father, or the youth recreation leaders they met in their own youth. In doing so, they contribute to further reinforcement of public discourses on the pedagogic potential of youth recreation work in general, and the importance of youth recreation leaders as role models in particular (cf. Blomdal \& Claesson, 1989; Bjurström, 2011). In short, students' talk about their occupational choice legitimises and makes possible the emergence of the role model.

Our analysis raises several questions which are in need of further elaboration. Firstly, the role model discourse emerging in our analysis defines the work of youth recreation leaders quite narrowly. Almost all students define youth recreation work as work which targets troubled youths in troubled suburban areas. This conceptualisation coincides with a wider public discourse on youth recreation work, exclusion and the notion of youth recreation leaders as role models. Youth recreation work is thus targeting people living abnormal lives, in what is construed as 'areas of exclusion', on the outskirts of the cities and society at large (see e.g. Dahlstedt \& Ekholm, 2016). On the one hand, the question therefore involves the role of these constructions in further stigmatising these young people who are the target of interventions, as well as the suburban areas which are targeted and construed as abnormal. On the other hand, the question involves what happens to all the young people who are not defined as abnormal, and thus not in need of support and guidance from the role model, or at least not to the same 
extent as the abnormal youths? In other words, who should be the target of youth recreation work?

Secondly, the analysis raises questions about the kind of society we live in, and the functions of welfare and education in this society. Are welfare and education a concern for all citizens, as equal bearers of welfare and education in terms of fundamental social rights, or are welfare and education a matter of reaching out to the excluded, by means of making them normal according to prevailing notions of normality?

Thirdly, as youth recreation work is constructed as something people learn and become based on their own experience of exclusion, what does this mean for youth recreation work as an occupation? Is a youth recreation leader something a person can become without having experienced exclusion, or is having a stigmatised and abnormal background necessary for becoming a youth recreation leader? What knowledge and competencies are needed to become a good worker in this specific occupation, and what knowledge and competencies are valued as important? These are all important questions of great interest for further scrutiny in the Swedish context, which is currently experiencing major challenges in terms of the exclusion of young people, and in terms of the possibilities as well as dilemmas of youth recreation work as a means of social inclusion.

\section{Acknowledgements}

We wish to acknowledge doctoral student Lina Rahm who has contributed to this work by conducting the data collection.

\section{References}

Billett, S., Newton, J., \& Ockerby, C. H. (2010). Socio-personal premises for selecting and securing an occupation as vocation. Studies in the education of adults, 42(1), 47-62.

Bjurström, E. (2011). Fritidens rum. Stockholm: Ungdomsstyrelsen.

Blomdahl, U. \& Claeson, Å. (1989). Fritidsgården - dess besökare och framtid. Stockholm: Fritid Stockholm.

Bloomer, M., \& Hodkinson, P. (2000). Learning careers. British Educational Research Journal, 26(5), 583-597.

Colley, H., D. James, \& Diment, K. (2007). Unbecoming teachers. Journal of Education Policy, 22(2), 173-193.

Colley, H., D. James, K. Tedder, \& Diment, K. (2003). Learning as becoming in vocational education and training. Journal of Vocational Education and Training 55(4), 471-498.

Dahlstedt, M. (2009). Aktiveringens politik. Stockholm: Liber.

Dahlstedt, M. \& Lozic, V. (2016). Problematizing parents. In A. Ålund, (Ed.), Reimagineering the Nation (pp. XX-XX). Berlin: Peter Lang.

Dahlstedt, M. \& Ekholm, D. (2016).

Ecclestone, K., \& Pryor, J. (2003). 'Learning careers' or 'assessment careers'?. British Educational Research Journal, 29(4), 471-488.

Ekholm, D. (2016). Sport as a Means of Responding to Social Problems. Norrköping: Department of Social and Welfare Studies, Linköping University.

Fejes, A., \& Dahlstedt, M. (2014). The confessing society: Foucault, confession and practices of lifelong learning. London: Routledge.

Fejes, A. \& Nicoll, K. (eds) (2015). Foucault and a politics of confession in education. London: Routledge.

Fejes, A. \& Nicoll, K. (2010) A vocational calling: Exploring a caring technology within elderly care, Pedagogy, Culture \& Society, 18(3), 353-370. 
Fejes, A., Olson, M., Rahm, L., Dahlstedt, M., \& Sandberg, F. (2016). Individualisation in citizen formation in Swedish adult education. Scandinavian Journal of Educational Research, doi: 10.1080/00313831.2016.1258666.

Forkby, T., Johansson, H. \& Liljeholm Hansson, S. (2008). Främjande pedagogik. Göteborg: FoU i Väst/GR

Foucault, M. (2008). The Government of self and others. New York: Palgrave-MacMillan.

Foucault, M. (2007). Security, Territory, Population. Houndmills: Palgrave MacMillan.

Foucault, M. (1991). Discipline and Punish: The Birth of the Prison, Harmondsworth: Penguin.

Foucault, M. (1972). The Archaeology of Knowledge. New York: Harper.

Gottfredson, L. S., \& Lapan, R. T. (1997). Assessing gender-based circumscription of occupational aspirations. Journal of career assessment, 5(4), 419-441.

Hodkinson, P., \& Sparkes, A. W. (1997). Careership. British Journal of Sociology of Education, 18(1), 29-44.

Kihlström, A. \& Roos, H-E. (2000). Fritid och fritidsarbete i det senmoderna samhället. In L. Berggren (Ed.) Fritidskulturer (pp. 240-266). Lund: Studentlitteratur.

Laginder, A-M., Nordvall, H., \& Crowther, J. (2013). Popular education, power and democracy: Swedish experiences and contributions. Leicester: NIACE.

Nicoll, K., Fejes, A., Olson, M., Dahlstedt, M., \& Biesta, G. J.J. (2013). Opening discourses of citizenship education. Journal of Education Policy, 28(6), 828-846.

Öhlund, T. (2016). Sociala innovationer och institutionella traditioner. Stockholm: Institutionen för socialt arbete, Stockholms universitet.

Olson, M., Fejes, A., Dahlstedt, M., Nicoll, K. (2015). Citizenship discourses, British Journal of Sociology of Education, 36(7), 1036-1053. doi:10.1080/01425692.2014.883917

Peterson, A., Svensson, L.G. \& Addo, T. (2003). Ungdomar i vardagens väv. Lund: Studentlitteratur

Roos, H-E. (2000). Fritidens kunskapsområde. In L. Berggren (Ed.) Fritidskulturer (pp. XXXX) . Studentlitteratur: Lund:

Sandberg, F., Fejes, A., Dahlstedt, M., \& Olson, M. (2016). Adult education as a heterotopia of deviation. Adult Education Quarterly, 66(2), 103-119.

Simpson, R. (2005). Men in non-traditional occupations: Career entry, career orientation and experience of role strain. Gender, work and organization, 12(4), 363-380.

Sivan, A. (2003). Has leisure got anything to do with learning? Leisure studies, 22(2), 129146.

Trondman, M. (2008). Att förstå utsatthet. Stockholm: Fritze.

Ungdomsstyrelsen. (2008). Mötesplatser för unga. Stockholm: Ungdomsstyrelsen.

Volman, M., \& ten Dam, G. (2007). Learning and the development of social identities in the subjects Care and Technology. British Educational Research Journal 33(6), 845-866.

Wernesjö, U. (2014). Conditional belonging: Listening to unaccompanied young refugees' voices. Uppsala: Uppsala University. 